\title{
Mithramycin Blocks Protein Binding and Function of the SV40 Early Promoter
}

\author{
Ratna Ray, ${ }^{*}$ Richard C. Snyder, ${ }^{*}$ Shelia Thomas, ${ }^{\ddagger}$ Charles A. Koller, ${ }^{\mathbf{6}}$ and Donald M. Miller* \\ *Department of Internal Medicine and Biochemistry, Comprehensive Cancer Center, University of Alabama at Birmingham, \\ Birmingham, Alabama 35294; ${ }^{\ddagger}$ Birmingham Veterans Administration Medical Center, Birmingham, Alabama 35294; and \\ $\$$ M. D. Anderson Hospital, Houston, Texas 77030
}

\begin{abstract}
Specific interactions between DNA and transcription factors are necessary for transcription initiation. These interactions provide a potential target for the selective inhibition of eukaryotic gene expression. Mithramycin is a DNA binding antibiotic which, in the presence of $\mathbf{M g}^{2+}$, binds $\mathbf{G}-\mathrm{C}$ containing sequences in the minor groove. The SV40 early promoter contains six G-C decanucleotide sequences, which are binding sites for the transcriptional activating factor, Sp1. Each of the six Sp1 binding sites of this promoter is protected from DNAse 1 digestion by mithramycin binding. Mithramycin binding to the G-C rich sequences in the SV40 early promoter prevents subsequent protein binding to these sequences. The gel retardation of the SV40 early promoter fragment incubated with a HeLa cell extract is completely abrogated by pretreatment of the DNA fragment with mithramycin. The functional significance of mithramycin binding is reflected in the ability of mithramycin to block promoter function. Mithramycin inhibits promoter dependent transcription in an in vitro runoff transcription system in a concentration dependent manner. This suggests that mithramycin prevents transcriptional activation of the SV40 early promoter by blocking binding of transcriptional activating proteins to $\mathbf{G}-\mathbf{C}$ rich promoter regions.
\end{abstract}

\section{Introduction}

Gene expression in higher eukaryotic cells is mediated by systematic control of RNA synthesis. Formation of the transcription initiation complex involves interaction of a number of cellular factors which bind specific DNA sequences located within the promoter regions of eukaryotic genes (1-4). It is likely that both temporal and tissue specific gene expression are controlled, at least in part, by the interaction of these factors with DNA.

The most well characterized transcription factor is Spl (5) which was first detected in HeLa cells on the basis of its ability to activate the SV40 early promoter. Tjian and his co-workers have shown that $\mathrm{Sp} 1$ recognizes and binds selectively to a GC rich decanucleotide sequence $(6,7)$. This "G-C box" sequence is present as six tandem copies in SV40 early promoter. Spl interacts with the GC box sequences by forming protein-DNA

Address reprint requests to Dr. Miller, Department of Internal Medicine and Biochemistry, University of Alabama at Birmingham, 1918 University Boulevard, BHSB 288, Birmingham, AL 35294.

Received for publication 1 August 1988 and in revised form 4 January 1989.

J. Clin. Invest.

(c) The American Society for Clinical Investigation, Inc. 0021-9738/89/06/2003/05 $\$ 2.00$

Volume 83, June 1989, 2003-2007 complexes in the major groove of DNA. Sp1 binding appears to be necessary for transcriptional activation of the SV40 early promoter (6-12).

Spl can also activate transcription of other viral and cellular genes which have one or more GC box elements in their $5^{\prime}$ flanking promoter sequences. Genes whose promoters contain such sequences include the HSV-TK (herpes simplex virusthymidine kinase) (13), human metallothionein $\mathrm{II}_{\mathrm{A}}(14)$, dihydrofolate reductase (15), and the Ha-ras protooncogene (16). The human c-myc gene also has short G-C rich sequences $5^{\prime}$ of both the $\mathrm{P} 1$ and $\mathrm{P} 2$ promoters, but does not contain consensus Spl binding sites. The importance of these sequences in the regulation of cellular gene expression is not known.

Mithramycin is a G-C specific DNA binding antibiotic that inhibits RNA synthesis initiation $(17,18)$. It inhibits binding of Escherichia coli RNA polymerase to a poly $\mathrm{dG} \cdot \mathrm{dC}$ template, but does not inhibit binding to a poly $\mathrm{dA} \cdot \mathrm{dT}$ template (18). This suggests that mithramycin may bind to G-C-rich sequences in eukaryotic promoters and inhibit RNA synthesis by preventing binding of regulatory proteins, such as $\mathrm{Sp} 1$, to these sites.

Mithramycin is an effective differentiating agent of HL60 promyelocytic leukemia cells, as well as the leukemic cells of certain patients with the myeloid blast phase of chronic myelogenous leukemia $(19,20)$. Treatment of leukemic cells with this agent is accompanied by an early dramatic decrease in c-myc expression, which precedes differentiation by 24-48 h. Expression of the c-myc protooncogene is selectively inhibited by mithramycin treatment in a number of differentiating and nondifferentiating cell types (21).

We have used the SV40 early promoter sequence to correlate the specificity and effects of mithramycin binding. The results of these experiments indicate that this compound prevents formation of the transcription initiation complex by binding to $\mathrm{G}-\mathrm{C}$-rich promoter regions.

\section{Methods}

DNAse 1 footprinting. Plasmid PL1 (22) containing the SV40 early promoter was first digested with $\mathrm{Ncol}$ and $3^{\prime}$ labeled with $\left[{ }^{32} \mathrm{P}\right] \mathrm{dCTP}$ and the Klenow fragment of DNA polymerase. Digestion with Nsil yielded the labeled 89-bp fragment containing the SV40 early promoter sequences shown in Fig. $1 A$. This fragment was isolated by electrophoresis on a $10 \%$ polyacrylamide gel. $3^{\prime}$ labeled DNA $(35,000$ cpm) was incubated with or without mithramycin at $37^{\circ} \mathrm{C}$ for $20 \mathrm{~min}$ in presence of $3 \mathrm{mM} \mathrm{MgCl} 2.1 \mathrm{U}$ of DNAse 1 was added and after 1 min the reaction was terminated with formamide dye. Guanine and cytosine specific chemical sequencing reactions of $3^{\prime}$ labeled SV40 early promoter fragment were used as a marker (23). The samples were analyzed on a $12 \%$ urea-acrylamide sequencing gel.

Gel binding analysis. The nuclear extract was prepared from HeLa cells as described by Dignam et al. (24). The DNA-protein binding reaction was carried out in $10 \mathrm{mM}$ Tris- $\mathrm{HCl}$ (pH 7.5), $100 \mathrm{mM} \mathrm{NaCl}, 1$ mM EDTA, $1 \mathrm{mM} \beta$-mercaptoethanol, $4 \%$ glycerol, $2.5 \mu \mathrm{g}$ poly d(I-C) 


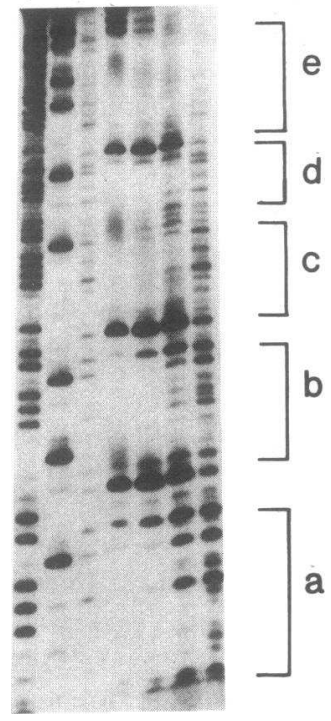

B

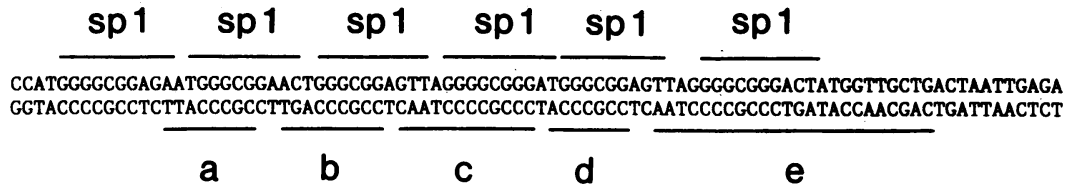

Figure 1. DNAse 1 footprinting analysis of mithramycin binding to the SV40 promoter region. An 89-bp fragment of the SV40 promoter (Fig. $1 A$ ) containing six G-C boxes was used for DNAse 1 footprinting reactions. The footprint result $(B)$ shows that most of the $G$ and $C$ residues were protected by mithramycin. The sequence of protected G-C region corresponds to the "G-C" box regions of the early promoter of SV40. (Lane 1) Cytosinespecific reaction using Maxam Gilbert method; (lane 2) guanine specific reaction using Maxam Gilbert method; (lane 3) DNAse 1 treated, 3' end labeled 89 bp SV40 early promoter fragment; (lane 4) DNAse 1 digestion of the $3^{\prime}$ labeled fragment in the presence of $100 \mu \mathrm{M}$ mithramycin; (lane 5) $10 \mu \mathrm{M}$ mithramycin; (lane 6) $1 \mu \mathrm{M}$ mithramycin; (lane 7) $0.1 \mu \mathrm{M}$ mithramycin. The areas of the gel identified as $a-e$ represent the G-C-rich regions which are selectively protected by mithramycin binding. for 20-40 $\mathrm{min}$ at room temperature (25). Each reaction contained $20,000 \mathrm{cpm}$ of $3^{\prime}$ labeled DNA, $8 \mu \mathrm{g}$ of nuclear extract, and varying concentrations of mithramycin in a final volume $15 \mu \mathrm{l}$. The binding mixture was analyzed by electrophoresis on a $5 \%$ polyacrylamide gel containing $40 \mathrm{mM}$ Tris-acetate, $1 \mathrm{mM}$ EDTA.

In vitro transcription with whole cell extracts. The polymerase-II rich whole cèll extract $(9 \mathrm{mg} / \mathrm{ml})$ prepared from HeLa cells according to Manley (26). A standard 25- $\mu$ l reaction mixture consisting of $17 \mu \mathrm{l}$ of whole cell extract; $1.5 \mu \mathrm{g}$ of DNA template, $50 \mathrm{mM}$ of CTP, ATP, GTP, and UTP, $4 \mathrm{mM}$ creatine phosphate, $10 \mu \mathrm{Ci}\left[{ }^{32} \mathrm{P}\right] \mathrm{GTP}$ or UTP $(410 \mathrm{Ci} / \mathrm{mmol}$; Amersham Corp., Arlington Heights, IL) was incubated for $60 \mathrm{~min}$ at $30^{\circ} \mathrm{C}$. The reaction was terminated by the addition of $100 \mu$ l of termination buffer ( $1 \%$ sarkosyl, $100 \mathrm{mM} \mathrm{NaCl}, 100 \mathrm{mM}$ Tris- $\mathrm{HCl}, \mathrm{pH} 8.0100 \mathrm{mM}$ EDTA) and extracted twice with phenol followed by chloroform, and ethanol precipitation. The reaction mix was analyzed by electrophoresis on a $6 \%$ polyacrylamide-urea gel.

\section{Results}

The mithramycin binding sites on the SV40 early promoter were determined by DNAse I protection assays. Fig. 1 shows the binding of mithramycin to the SV40 promoter region as detected by the DNAse I protection. An 89-bp fragment of the SV40 promoter region (Fig. $1 A$ ), which contains the six "G-C box" recognition sites for $\mathrm{Sp} 1$, was incubated with varying concentrations of mithramycin before DNAse I digestion. As shown in Fig. $1 \mathrm{~B}$, mithramycin binds selectively to the G-C box regions of the SV40 promoter, in a fashion nearly identical to binding of Sp1 (10). It also binds to shorter G-C containing sequences in this DNA fragment, although to a lesser degree. The footprinting pattern is mithramycin concentration dependent (data not shown) and maximal binding occurs at DNA/mithramycin ratios that result in RNA synthesis inhibi- tion. Mithramycin appears to require at least three consecutive $\mathrm{G}$ or $\mathrm{C}$ residues for effective binding. This is consistant with the previous observations regarding mithramycin binding to the lac operon (27).

Binding of the partially purified recombinant Spl product of the Sp1-516c plasmid and mithramycin were compared as shown in Fig. 2. The binding patterns of mithramycin and the recombinant Sp1 to the G-C-rich portion of the SV40 early promoter were similar, but not identical. Mithramycin appears to recognize all of the sequences bound by $\mathrm{Sp} 1$, but also binds to additional G-C-rich sequences. This most likely reflects the smaller size of the drug compared to the recombinant Sp1.

Gel retardation studies were used to determine whether the binding of mithramycin to the G-C box regions of the SV40 early promoter region may prevent sequence-specific protein binding. The effect of mithramycin binding on the specific changes in gel mobility of the SV40 early promoter fragment, induced by a partially purified HeLa cell extract, enriched in Spl were examined. As shown in Fig. $3 A$, binding of mithramycin blocks specific binding of proteins to the 89-bp fragment of the SV40 promoter, as reflected by the loss of gel mobility retardation. Treatment of the DNA fragment with the HeLa cell extract, but not mithramycin alone, resulted in retardation of the fragment containing the SV40 promoter region. Three retarded bands were seen in the nuclear extract treated larger DNA fragment, most likely representing binding by different proteins or combinations of proteins to this portion of the SV40 promoter sequence.

Higher mithramycin concentrations prevented the gel mobility shift of all three bands binding to the 89-bp fragment, whereas the binding of the more specific band was restored at 


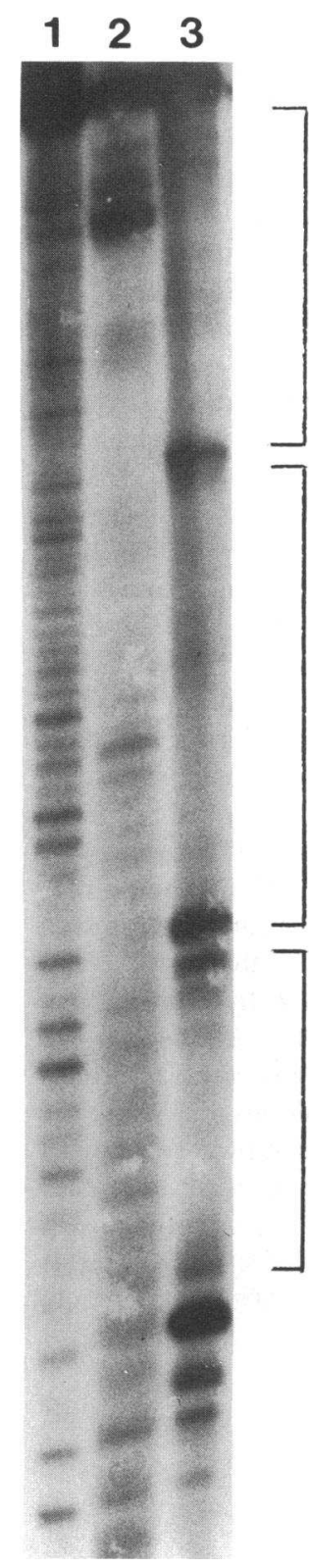

Figure 2. DNAse 1 footprinting of the SV40 early promoter with recombinant Sp1. The plasmid pSp1-516c was obtained from J. Kadonaga and R. Tjian. A crude extract was made according to Kadonaga et al. (28). Mithramycin-DNA binding and the DNAse 1 reaction was performed as described in Methods. Sp1-516c protein and DNA binding was performed at $0^{\circ} \mathrm{C}$ for $30 \mathrm{~min}$. The Spl footprint is indicated by the bracket. (Lane 1) Labeled DNA treated with DNAse 1; (lane 2) Labeled DNA treated with DNAse 1 in the presence of $1 \mathrm{mM}$ mithramycin; (lane 3) Labeled DNA preincubated with Sp1-516c (10 $\mu$ g protein) followed by DNAse 1 digestion.

lower mithramycin concentrations. Fig. $3 B$ shows that gel mobility experiments using a smaller 70-bp fragment demonstrate only one retarded band, which is absent when the fragment is preincubated in the presence of mithramycin. This indicates that specific binding of mithramycin to the G-C-rich areas of this promoter sequence is able to prevent subsequent protein binding to the G-C box regions of the SV40 promoter. Mithramycin does not appear to be capable of displacing proteins that have already bound to the DNA. The HeLa cell extract used for these experiments contains relatively high amounts of the $\mathrm{Sp} 1$ regulatory protein, which is most likely responsible for the single retarded band shown in Fig. $3 \mathrm{~B}$.

The gel mobility shift analysis of recombinant $\mathrm{Sp} 1$ (Sp1-516c) binding to the SV40 early promoter in the presence or absence of mithramycin is shown in Fig. 4. This experiment demonstrates that recombinant $\mathrm{Sp} 1$ is unable to bind to the SV40 early promoter when the DNA has been preincubated with mithramycin (lane 2). However, in the absence of

mithramycin, Spl binds to the DNA (lane 1). This suggests that mithramycin and $\mathrm{Sp} 1$ recognize similar sequences, and that competitive binding of $\mathrm{Sp} 1$ binding sites by mithramycin prevents Spl binding.

To determine the functional effect of mithramycin binding to the SV40 promoter, we also measured the effect of mithramycin on the cell-free runoff transcription of this sequence by a whole cell HeLa cell extract (29). We determined the ability of the whole cell extract to transcribe the PL1 plasmid linearized with Eco RI (22). This plasmid contains both the SV40 early and late promoter region (shown in Fig. $5 A$ ) but RNA polymerase II transcribes only from the early promoter. As shown in Fig. $5 B$, the HeLa cell extract faithfully transcribes this sequence, yielding a RNA fragment of $200 \mathrm{bp}$ (lane 1). This transcription is inhibited by alpha-amanitin $(0.5 \mu \mathrm{g} / \mathrm{ml})$, indicating that RNA polymerase 2 activity is responsible for

A

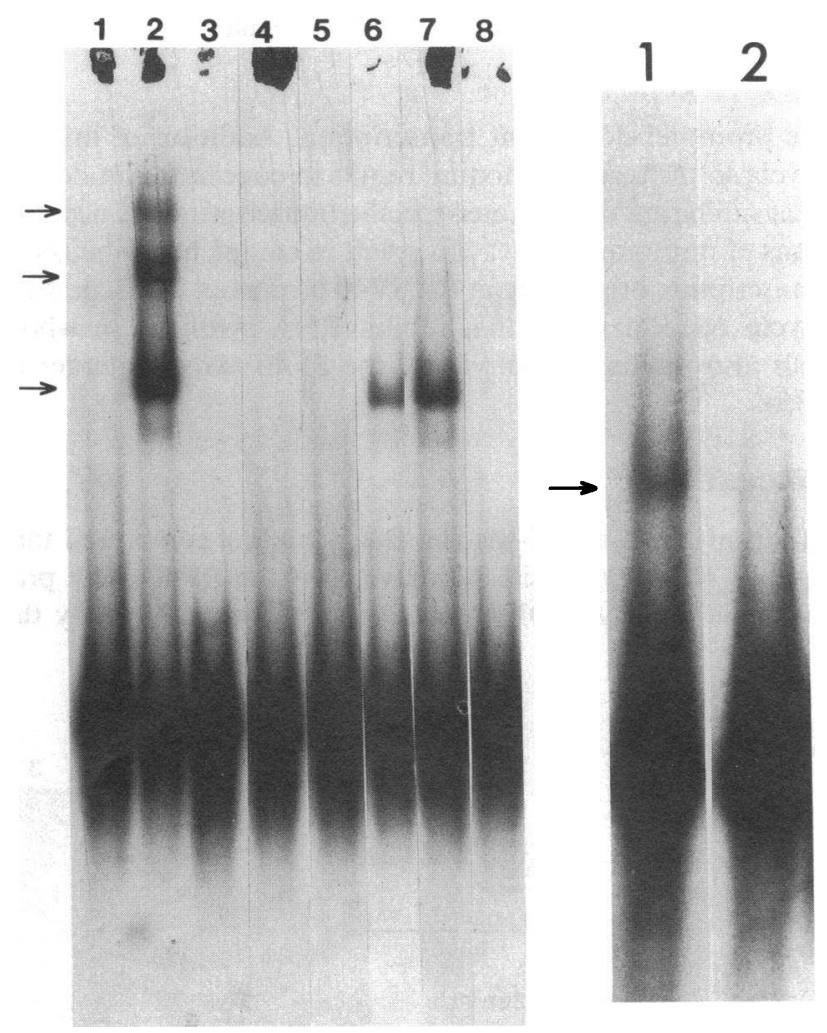

Figure 3. Gel mobility shift analysis of the SV40 early promoter with HeLa cell nuclear extract in the presence or absence of mithramycin. (A) $3^{\prime}$ labeled 89-bp fragment of the SV40 early promoter (described in Fig. 1) after incubation with the HeLa cell nuclear extract in the presence or absence of mithramycin. (Lane 1) DNA fragment only; (lane 2) DNA with HeLa cell extract (8 $\mu$ g protein); (lane 3) DNA preincubated with mithramycin $(1 \mathrm{mM})$ followed by the addition of HeLa cell nuclear extract ( $8 \mu$ g protein); (lane 4 ) Same as lane 3, but with $100 \mu \mathrm{M}$ mithramycin; (lane 5) $10 \mu \mathrm{M}$ mithramycin; (lane 6) 1 $\mu \mathrm{M}$ mithramycin; (lane 7) $0.1 \mu \mathrm{M}$ mithramycin; (lane 8$) 1 \mathrm{mM}$ mithramycin, preincubated with HeLa cell extract ( $8 \mu \mathrm{g}$ protein). $(B)$ $3^{\prime}$ labeled SphI-Hind III fragment of plasmid PL1 (70 bp) incubated with the HeLa cell nuclear extract $(8 \mu \mathrm{g})$ lane 1 ; SphI-Hind III fragment incubated with nuclear extract alone; (lane 2) SphI-Hind III fragment preincubated with mithramycin $(1 \mathrm{mM})$ followed by nuclear extract. Arrow indicates formation of protein DNA complex. 


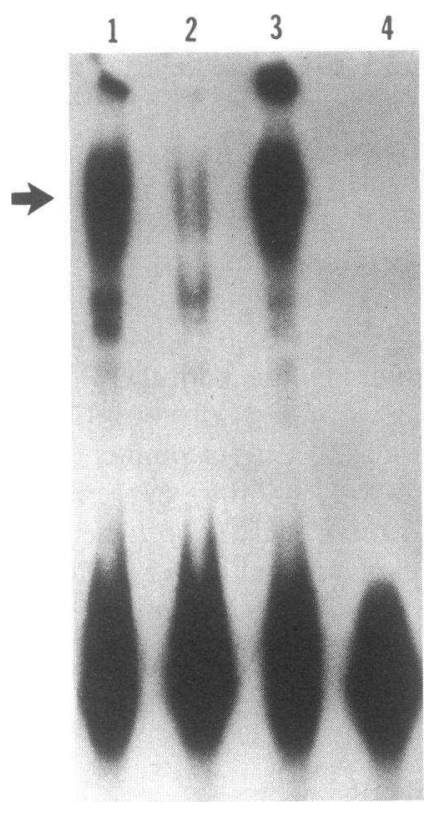

Figure 4. Gel retardation assay of SV40 early promoter with cloned Spl in the presence or absence of mithramycin. (Lane 1) DNA with Sp1-516c (10 $\mu \mathrm{g}$ protein); (lane 2) DNA preincubated with $1 \mathrm{mM}$ mithramycin, followed by the addition of Sp1-516c; (lane 3) DNA preincubated with $1 \mu \mathrm{M}$ mithramycin; (lane 4) labeled DNA. The binding conditions were those described in Methods and Fig. 2. Arrow indicates formation of protein DNA complex.

the promoter-dependent transcription. Addition of mithramycin to the reaction mixture results in concentration-dependent inhibition of promoter-specific transcription. Concentrations of mithramycin $>1 \mu \mathrm{M}$ result in complete inhibition of transcription originating at the SV40 promoter. Thus, mithramycin concentrations that inhibit RNA synthesis in whole cells also inhibit the activity of the SV40 early promoter in vitro.

\section{Discussion}

Mithramycin is a G-C-specific DNA binding compound that inhibits RNA synthesis. We have used the SV40 early promoter as prototype DNA sequence with which to study the specific functional effects of mithramycin binding. These studies have demonstrated that specific binding of mithramycin to G-C-rich regions of the SV40 early promoter results in a subsequent inability of proteins to bind to these sequences. This is accompanied by inhibition of promoter function. Our data suggest that mithramycin binds to important regulatory sequences within the SV40 early promoter, blocking binding of regulatory proteins to these sequences resulting in inhibition of transcription initiation complex formation, and decreased promoter function. The relative insensitivity of nuclear runoff transcription to mithramycin (18) indicates that transcription initiation is the site of mithramycin action and provides further support for this model.

Previous chemical footprinting studies of mithramycin and the related drugs, chromomycin and olivomycin (26) have demonstrated that at least three consecutive guanosine or cytosine nucleotides are necessary for mithramycin binding. More recent studies with echinomycin have suggested that chromatin structure may play a role in determining the binding ability and specific binding sites of these drugs (30). It is likely that both chromatin structure and sequence specificity determine the cellular effect of DNA binding drugs.

The G-C specificity of DNA binding by mithramycin suggests that expression of genes regulated by $\mathrm{G}-\mathrm{C}$ binding proteins may be selectively sensitive to this agent. This is supported by the observation that expression of the c-myc, c-Haras, and c- $a b l$ genes is selectively inhibited by mithramycin (21). These genes have G-C-rich promoter regions and the c-Ha-ras gene contains consensus Spl binding sites. The binding specificity of mithramycin for G-C residues may allow the selective inhibition of expression of a group of genes with $\mathrm{G}-\mathrm{C}$-rich promoters. Although the number of eukaryotic genes whose promoter regions contain G-C box sequences (or closely related sequences) is not known, a number of $\mathrm{Sp} 1$ binding sites of varying affinity have been identified (31). Mithramycin may inhibit expression of all of these genes to a varying degree.
A

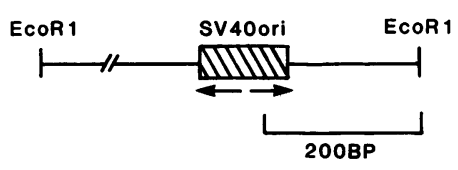

ECOR 1 LINEARIZED PL 1

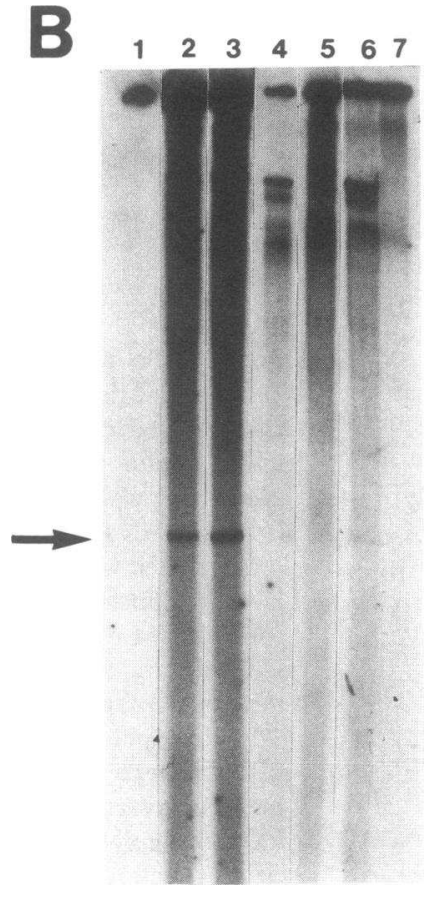

Figure 5. Effect of mithramycin on the in vitro runoff transcription of the SV40 early promoter. $(A)$ The PL1 plasmid template containing SV40 early promoter was linearized by Eco RI and the runoff transcription product was expected to be $\sim 200 \mathrm{bp}$. (B) (Lane 1) DNA only; lanes 2 and 3 show the transcript from DNA with whole cell extract using [ $\left.{ }^{32} \mathrm{P}\right] \mathrm{GTP}$ or $\left[{ }^{32} \mathrm{P}\right] \mathrm{UTP}$, respectively. (Lane 4) DNA fragment incubated with $4 \mathrm{mM}$ mithramycin at $37^{\circ} \mathrm{C}$ for $20 \mathrm{~min}$, followed by transcription assay; (lane 5) $40 \mu \mathrm{M}$ mithramycin; (lane 6) $0.4 \mu \mathrm{M}$ mithramycin; (lane 7) $0.04 \mu \mathrm{M}$ mithramycin. 
The cellular effects of mithramycin may be dictated by its selective inhibition of expression of genes with G-C-rich promoters. Mithramycin induces myeloid differentiation of leukemic cells in certain patients with chronic granulocytic leukemia $(18,19)$ which is accompanied by an early decrease in c-myc expression. The differentiation of leukemic cells in which c-myc expression is specifically inhibited by the presence of antisense DNA sequences $(32,33)$ suggests that decreased c-myc expression alone may be adequate to induce differentiation of these cells. Our data suggest that mithramycin may selectively block formation of the transcription initiation complex of genes with G-C-rich promoter regions, including the $c-m y c$ gene.

\section{Acknowledgments}

We thank Drs. J. Manley and G. Knapp for their helpful suggestions, and Dr. J. Kadonaga and R. Tjian for providing the Sp1-516c clone. We thank Mrs. Shiela Chastain for her expert assistance in the preparation of this manuscript.

Supported by grants for the Leukemia Society of America, National Cancer Institute (R01 CA-42664) and the Veterans Administration Research Office. Dr. Miller is a Clinical Investigator in the Veterans Administration Career Development Program.

\section{References}

1. Brown, D. D. 1984. The role of stable complexes that repress and activate eucaryotic genes. Cell. 37:359-365.

2. Lassar, A. B., P. L. Martin, and R. G. Roeder. 1983. Transcription of class III genes: formation of preinitiation complexes. Science (Wash. DC). 222:740-748.

3. Echols, H. 1986. Multiple DNA-protein interactions governing high-precision DNA transactions. Science (Wash. DC). 233:10501056.

4. Jones, K. A., and R. Tjian. 1985. Sp1 binds to promoter sequences and activates herpes simplex virus "immediate early" gene transcription in vitro. Nature (Lond.). 317:179-182.

5. Briggs, M. R., J. T. Kadonaga, S. P. Bell, and R. Tjian. 1986. Purification and biochemical characterization of the promoter-specific transcription factor, Sp1. Science (Wash. DC). 234:47-52.

6. Dynan, W. S., J. D. Saffer, W. S. Lee, and R. Tjian. 1985. Transcription factor $\mathrm{Sp} 1$ recognizes promoter sequences from the monkey genome that are similar to the simian virus 40 promoter. Proc. Natl. Acad. Sci. USA. 82:4915-4919.

7. Dynan, W. S., and R. Tjian. 1983. Isolation of transcription factors that discriminate between different promoters recognized by RNA polymerase II. Cell. 32:669-680.

8. Dynan, W. S., and R. Tjian. 1985. Control of eukaryotic messenger RNA synthesis by sequence-specific DNA-binding proteins. $\mathrm{Na}$ ture (Lond.). 316:774-778.

9. Jones, K. A., J. T. Kadonaga, P. J. Rosenfeld, T. J. Kelly, and R. Tjian. 1987. A cellular DNA-binding protein that activates eukaryotic transcription and DNA replication. Cell. 48:79-89.

10. Dynan, W. S., and R. Tjian. 1983. The promoter-specific transcription factor SP1 binds to upstream sequences in the SV40 early promoter. Cell. 35:79-87.

11. Kadonaga, J. T., and R. Tjian. 1986. Affinity purification of sequence-specific DNA binding proteins. Proc. Natl. Acad. Sci. USA. 83:5889-5893.

12. Gidoni, D., J. T. Kadonaga, H. Barrera-Saldana, K. Takahashi, P. Chambon, and R. Tjian. 1985. Bideyctional SV40 transcription mediated by transderm Spl binding interactions. Science (Wash. DC). 230:511-517.

13. Jones, K. A., K. R. Yamamoto, and R. Tjian. 1985. Two distinct transcription factors bind to the HSV thymidine kinase promoter in vitro. Cell. 42:559-572.
14. Lee, W., A. Haslinger, M. Karin, and R. Tjian. 1987. Activation of transcription by two factors that bind promoter and enhancer sequences of the human metallothionein gene and SV40. Nature (Lond.). 325:368-372.

15. Dynan, W. S., S. Sazer, R. Tjian, and R. T. Schimke, 1986. Transcription factor Sp1 recognizes a DNA sequence in the mouse dihydrofolate reductase promoter. Nature (Lond.). 319:246-248.

16. Ishii, S., J. T. Kadonaga, R. Tjian, J. N. Brady, G. T. Merlino, and I. Pastan. 1986. Binding of the Spl transcription factor by the human Harvey ras1 proto-oncogene promoter. Science (Wash. DC). 232:1410-1413.

17. Yarbro, J. W., B. J. Kennedy, and C. P. Barnum. 1968. Mithramycin inhibition of ribonucleic acid synthesis. Cancer Res. 26:36-39.

18. Miller, D. M., D. A. Polansky, S. D. Thomas, R. Ray, V. W. Campbell, J. Sanchez, and C. A. Koller. 1987. Rapid communication: Mithramycin selectively inhibits transcription of G-C containing DNA. Am. J. Med. Sci. 294:388-394.

19. Koller, C. A., and D. M. Miller. 1986. Preliminary observations on the therapy of the myeloid blast phase of chronic granulocytic leukemia with plicamycin and hydroxyurea. N. Engl. J. Med. 315:1433-1438.

20. Koller, C. A., V. W. Campbell, A. Yang, A. Mulhern, and D. M. Miller. 1985. Expression of c-myc and c-abl protooncogenes during in vivo differentiation of blast phase chronic granulocytic leukemia. J. Clin. Invest. 76:365-369.

21. Miller, D. M., V. Baker, S. Thomas, D. Rigsby, J. D. Sanchez, and C. A. Koller. 1986. Selective inhibition of c-myc expression by the RNA synthesis inhibitor mithramycin. Blood. 68:260a. (Abstr.)

22. Okayama, H., and P. Berg. 1983. A cDNA cloning vector that permits expression of cDNA inserts in mammalian cells. Mol. Cell Biol. 3:280-289.

23. Maxam, A., and W. Gilbert. 1980. Sequencing end-labelling DNA with base-specific chemical cleavages. Methods Enzymol. 65:499-560.

24. Dignam, J. D., R. M. Lebovitz, and R. G. Roeder. 1983. Accurate transcription initiation by RNA polymerase II in a soluble extract from isolated mammalian nuclei. Nucleic Acids Res. 11:1475-1481.

25. Sen, R., and D. Baltimore. 1986. Inducibility of kappa immunoglobulin enhancer-binding protein Nf-kappa B by a posttranslational mechanism. Cell. 47:921-929.

26. Van Dyke, M. W., and P. B. Dervan. 1983. Chromomycin, mithramycin, and olivomycin binding sites on heterogeneous deoxyribonucleic acid. Footprinting with (methidiumpropyl-EDTA)iron(II). Biochemistry. 22:2373-2377.

27. Dervan, P. B. 1986. Design of sequence-specific DNA-binding molecules. Science (Wash. DC). 232:464-471.

28. Kadonaga, J. T., K. R. Carner, F. R. Masiarz, and R. Tjian. 1987. Isolation of cDNA encoding transcription factor $\mathrm{Sp} 1$ and functional analysis of the DNA binding domain. Cell. 51:1079-1090.

29. Manly, J. D. 1984. Transcription of eukaryotic genes in wholecell extract. In Transcription and Translation. B. D. Hamese and S. J. Higgins, editors. IRL Press, Oxford. 71-88.

30. Low, C. M. L., H. R. Drew, and M. J. Waring. 1984. Sequence-specific binding of echinomycin to DNA: evidence for conformational changes affecting flanking sequences. Nucleic Acids Res. 12:4865-4879.

31. Kadonaga, J. T., K. A. Jones, and T. Tjian. 1986. Promoterspecific activation of RNA polymerase II transcription by Sp1. Trends Biochem. Sci. 11:20-25.

32. Holt, J. T., R. L. Redner, and A. W. Neinhuis. 1988. An oligomer complementary to c-myc mRNA inhibits proliferation of HL-60 promyelocytic cells and induces differentiation. Mol. Cell. Biol. 8:963-973.

33. Yokoyama, L., and F. Imamato. 1987. Transcriptional control of the endogenous myc protooncogene by antisense RNA. Proc. Natl. Acad. Sci. USA. 84:7363-7367. 